\title{
ПРИНЯТИЕ КОНСТИТУЦИОННЫМ СУДОМ АЗЕРБАЙДЖАНСКОЙ РЕСПУБЛИКИ ЗАПРОСОВ И ОБРАЩЕНИЙ ДЛЯ ОСМОТРА И ПОДГОТОВКИ К СУДЕБНОМУ РАССМОТРЕНИЮ
}

\author{
ШЮКЮРОВ Насиб Хейбат оглы - кандидат юридических наук, доцент \\ кафедры «Конституционного права» Бакинского государственного университета
}

DOI:10.32782/NP.2020.1.3

В статье проводится широкое исследование важной роли конституиионного контроля в период совершенствования судебной правовой системы, рассматривается масштаб и последовательность дел в конституционном судопроизводстве, а также вопросъ рассмотрения по существу запросов, обращений и жалоб, и особого конституиионного производства.

Кроме того, в статье обсуждается важность доклада судьи-докладчика по существу дела в конституиионном судопроизводстве, широких прочессуальных прав председателя заседания Конституционного суда, бълли также проанализированъ имеюшие важное значение вопросъг привлечения экспертов, свидетелей, специалистов и переводчиков для участия в конституиионном судопроизводстве.

Ключевъе слова: конституционное судопроизводство, запросъ, обращения и жалобъ, поданнъге в конституционнъий суд, специальное конституционное производство, судья-докладчик, принятие решения Конституционнъим судом.

Следует отметить, что на этапе принятия конституционной жалобы к рассмотрению вначале принимается окончательное решение о том, что жалоба заявителя должна быть рассмотрена или же отклонена Конституционным судом. Согласно статье 12-й Внутреннего устава Конституционного суда, после завершения подготовительного этапа заседаний палат Конституционного суда, предусмотренное в статьях III и VII статьи 130-й Конституции Азербайджанской Pe- спублики и статьях 32-34 Закона Азербайджанской Республики «О Конституционном суде» решение вопроса о принятии к производству или об отклонении принятия к производству запросов, обращений или жалоб, направляется на заседания палат Конституционного суда, а решение вопроса обращения предусмотренного в статье 58.1 Закона Азербайджанской Республики «О Конституционном суде», выносится на заседания Пленума Конституционного суда.

Стороны (заявители) или заинтересованные субъекты могут быть заранее уведомлены о месте и времени проведения заседаний палат и Пленума Конституционного суда о принятии к производству запросов, обращений или жалоб. Только судьи соответствующей палаты могут присутствовать на заседаниях палат Конституционного суда, по поводу принятия к производству или отказа от принятия к производству запросов, обращений или жалоб. Судьи палат, поочередно председательствуют на заседаниях палат. При необходимости стороны (заявители), заинтересованные субъекты и другие лица могут быть приглашены на заседания палат Конституционного суда.

Вопрос о принятии к производству запросов, обращений или жалоб по вопросам, предусмотренным частью III-VII статьи 130-й Конституции Азербайджанской Республики, решается на заседаниях палат Конституционного суда. А вот заседания палат, в свою очередь правомочны, если на них присутствуют как минимум трое судей. В то же 
время вопросы, предусмотренные статьей 86-й, частью I статьи 88-й, статьей 102-й, частями II и III статьи 104-й, статьями 107-й и 153-й Конституции Азербайджанской Республики, непосредственно рассматриваются на заседаниях Пленума Конституционного суда. По обращению, предусмотренному в статье 58.1-й Закона Азербайджанской Республики «О Конституционном суде», Пленум правомочен в присутствии на его заседании не менее 6-и судей. Пленарное заседание Конституционного суда проводится в соответствии с правилами, предусмотренными в части III статьи 12-й Внутреннего устава Конституционного суда.

Палаты и Пленум Конституционного суда выносят отдельное определение о допуске или отказе к рассмотрению каждого запроса, обращения или жалобы, и это определение находит отражение в протоколе заседания Конституционного суда. Определения палат и Пленума Конституционного суда по запросу, обращению или жалобе - должны быть обоснованы.

В случае отказа от предложения судьидокладчика - принятия к производству запроса, обращения или жалобы, он на основании обсуждений подготавливает текст решения Конституционного суда - об отказе в принятии к производству запроса, обращения или жалобы. Если основания для отказа в принятии к производству запроса, обращения или жалобы не вполне ясны судье-докладчику, то судьи, проголосовавшие за это определение, судье-докладчику представляют свои аргументы в письменном виде.

В случаях, предусмотренных статьями 37.0.1, 37.0.2 и 37.0.5 Закона Азербайджанской Республики «О Конституционном суде», после вынесения определения об отказе принятия к производству жалобы в Конституционный суд, жалоба поданная тем же заявителем в сроки, указанные в статьях 34.4.1 и 34.4.2 Закона, передается в палату Конституционного суда Азербайджанской Республики. Если заявитель не изменяет оснований новой жалобы, поданной по тому же предмету, Конституционный суд Азербайджанской Республики выносит определение об отказе принятия жалобы к производству в Конституционный суд, и после этого переписка с заявителем прекращается.

Определения палат и Пленума Конституционного суда о принятии или об отказе от принятия к производству Конституционном судом запроса или жалобы направляются не позднее, чем по истечении семи дней со дня его принятия - сторонам (заявителям) или заинтересованным субъектам, а вот определение о рассмотрении обращения Милли Меджлиса Азербайджанской Республики по выяснению информации - о полной утрате Президентом Азербайджанской Республики по состоянию здоровья способности исполнять свои полномочия, направляется в тот же день. Вместе с определениями о принятии к производству запроса, обращения или жалобы в Конституционный суд, направлением сторонам - запроса или жалобы, а заинтересованным субъектам документов другого вида, их просят представить в Конституционный суд свои письменные мнения по этому вопросу.

После предварительного рассмотрения жалобы Конституционный суд на заседании одной из палат может вынести одно из возможных определений: принятие жалобы к производству; отказ от принятия к производству. По мнению В.О.Аучина и О.Н.Дорониной, важность принятия этого решения на расширенном заседании исходит из того, что распределение дел, принятых к разбирательству между палатами и Пленумом суда, следует проводить именно при широком обсуждении. С другой стороны, они отмечают, что эта процедура значительно замедляет ход конституционного судопроизводства по жалобе, и считают, что целесообразным было бы закрепление в законе возможности палате вынесения определений о принятии к производству или отклонении жалобы, а распределение дел, принятых к производству, возложить на председателя Конституционного суда (8, c.86).

Невозможность рассмотрения жалобы Конституционным судом является основанием для отказа в принятии к производству жалобы. 


\section{Теорія, історія держави і права, конституційне право}

Конституционный суд Азербайджанской Республики может принять решение об отказе в принятии к производству жалобы в нижеследующих случаях:

1) при несоответствии составления запроса, обращения или жалобы требованиям настоящего Закона;

2) в случае, если вопрос не относится к полномочиям Конституционного суда;

3) при подаче запроса, обращения или жалобы органом или лицом, не обладающим таким правом;

4) в случае подачи запроса или обращения при отсутствии на заседании коллегиального органа, принявшего решение о его подаче в Конституционный суд, кворума и необходимого большинства голосов;

5) в случае, если не представлены документы, подтверждающие полное использование права обжалования судебного акта или нарушение права обращения в суд;

6) при наличии решения Конституционного суда по вопросу.

В юридической литературе существуют различные мнения по поводу возврата жалобы Аппаратом Конституционного суда и уведомлении заявителя о том, что жалоба не была составлена в соответствии с требованиями закона. По мнению некоторых авторов, Аппарат Конституционного суда может отказать в рассмотрении дела (4, с. 130), в то время как другие авторы отмечают, что Аппарат не может отказать в принятии обращения заявителя, он может только уведомлять, проверять наличие оснований для рассмотрения дела в Конституционном суде, а эти основания выявляются уже в ходе разбирательства, и только сам суд имеет такое право (право отказа от рассмотрения дела) (9, c.188-192).

Меры, осуществляемые для предварительного рассмотрения жалобы на первом этапе конституционного судебного процесса, имеют особое значение для принятия решения о том, принять ли ее к производству для рассмотрения в Конституционном суде.

Специалисты Аппарата Конституционного суда определяют соответствие жалобы следующим предварительным условиям, для ее принятия к производству:
- подсудность жалобы полномочиям суда в соответствии со статьей 130 Конституции Азербайджанской Республики и статьей 3 Закона Азербайджанской Республики «О Конституционном суде»;

- соответствие жалобы установленной законом форме;

- субъектность заявителя.

Если одно из этих требований не обеспечивается, Аппарат Конституционного суда уведомляет заявителя о том, что его обращение не соответствует требованиям закона. Целью отправки такой информации является не только информирование заявителя, но и прекращение всех действий, связанных с его обращением.

Практика показывает, что большинство жалоб, поступивших в Конституционный суд, фактически не относится к его полномочиям. В этих жалобах ставятся вопросы пересмотра или отмены судебных приговоров и решений, запроса документов, наказание должностных лиц, проведение расследования, обеспечение исполнения тех или иных правовых актов, помощь в получении или разделении квартиры, разъяснения по сущности законов и судебных решений. Аппарат Конституционного суда может направить такие обращения по адресу полномочного государственного органа и об этом должен уведомить заявителя. В целом, деятельность Аппарата служит для облегчения последующей работы судей Конституционного суда по изучению обращений граждан.

Основания для возврата Аппаратом жалобы частично совпадают с основаниями отказа палаты в принятии жалобы к производству, предусмотренными в статье 37.0.1 Закона «О Конституционном суде» (при несоответствии составления жалобы требованиям настоящего Закона).

Одной из особенностей конституционного производства выступает институт отзыва запросов, обращений и жалоб. Согласно статье 38-й Закона «О Конституционном суде», при отзыве запроса, обращения или жалобы, поданных в Конституционный суд, до принятия их к производству Конституционного суда, данные запрос, обращение или жалоба не рассматриваются в Конституционном суде. Конституционный суд Азер- 
байджанской Республики не требует указания причин отзыва запроса, обращения или жалобы.

Таким образом, решение вопросов, обязательных для данного этапа, - установление подсудности дела Конституционным судом, изучение материалов дела и подготовка заключения по его итогам, при отсутствии оснований для отказа о принятии жалобы к производству - завершается вынесением определения о его принятии к производству.

После принятия решения о принятии обращения к рассмотрению в Конституционном суде, производство дела переходит к этапу его назначения для рассмотрения на Пленуме Конституционного суда. По мнению В.А.Кряжкова и Л.В.Лазарева, с момента назначения дела к рассмотрению и до соответствующих заседаний, осуществляются действия следующей направленности:

- установление обстоятельств, обладающих значением для правильного разрешения дела;

- установление руководящих конституционных и иных правовых положений;

- решение вопроса, связанного с составом лиц, участвующих в деле;

- установление доказательств, которые должны быть получены от сторон и других лиц $(7$, с. 207$)$.

Х.Б. Шейнин отмечает, что назначение дела к рассмотрению является важным этапом конституционного судопроизводства, и в ходе него решаются как минимум три вопроса:

1) установление уровня подготовки материалов дела к рассмотрению в судебном заседании;

2) установление последовательности рассмотрения отдельных дел;

3) установление состава суда для рассмотрения дела (на заседании Пленума или в одной из палат) $(6$, с.163).

Принятие запроса, обращения или жалобы для рассмотрения, ставит перед Конституционным судом обязательство совершить подготовительные дела. Н.В.Витрук указывает, что подготовительный этап имеет целью обеспечение всех необходимых условий для оперативного и эффективного рассмотрения дела (5, с. 235).

В соответствии со статьей 15-й Внутреннего устава Конституционного суда, время и дата рассмотрения конституционного дела Пленумом Конституционного суда назначаются Председателем Конституционного суда.

Порядок установления очередности рассмотрения конституционных дел Пленумом Конституционного суда определен во второй части статьи 15-й Внутреннего устава. Там указывается, что Председатель Конституционного суда при определении порядка рассмотрения конституционных дел на Пленуме Конституционного суда должен учитывать последовательность поступления запросов, обращения и жалоб. В неотложных случаях председатель Конституционного суда может изменить порядок очередности рассмотрения дел. Однако разные сроки изучения судьями обращений, различный объем дел в палатах, замена судьи-докладчика и т.п. случаи, могут обусловить рассмотрение некоторых дел за более короткий период времени и продление сроков рассмотрения других дел (2, с. 213-214).

Закон «О Конституционном суде», в зависимости от вида производства, после принятия дела к рассмотрению, устанавливает различные сроки рассмотрения его по существу. Например, для запросов и жалоб, связанных с вопросами, предусмотренными в пунктах 1-7 части III статьи 130-й, частях V и VII Конституции Азербайджанской Республики, а также для запросов и обращений по толкованию Конституции и законов, -этот период должен составлять не позднее 60 дней с даты их принятия к производству; не позднее 30 дней в связи со спорами о разделении полномочий (статьи 52, 53 и 60-я Закона «О Конституционном суде»). Однако по усмотрению Конституционного суда, эти сроки могут быть продлены при необходимости и наличии реальных оснований.

В юридической литературе, при принятии решения о назначении конституционного дела для рассмотрения на Пленуме Конституционного суда, предлагается указывать порядок очередности рассмотрения этого дела $(6$, с.163). Это позволяет, с одной 


\section{Теорія, історія держави і права, конституційне право}

стороны, учитывать с объективной стороны подготовленность дела к рассмотрению, а с другой стороны, исключает возможность неоправданного продления или, наоборот, ускорения рассмотрения дела.

Как известно, предметом рассмотрения дела в конституционном производстве выступает нормативный правовой акт, договор или его часть, оспариваемые полномочия органов государственной власти, нормы Конституции или закона, которые должны толковаться. Дела по запросам, обращениям и жалобам, касающимся одного и того же предмета (например, обращения, направленные на проверку соответствия конституции одного и того же акта или толкование одной и той же нормы (норм) Конституции), могут быть объединены в едином производстве. Так, в соответствии со статьей 17-й Внутреннего устава Конституционного суда, запросы, обращения и жалобы по одному и тому же предмету, Конституционный суд может объединять в едином производстве. Вопрос же об объединении конституционных дел в единое производство решается на заседании Пленума Конституционного суда до рассмотрения дела по существу, и об этом выносится определение путем внесения соответствующих отметок в протокол. В соответствии со статьей 21.0.7 Закона Азербайджанской Республики «О Конституционном Суде», Председатель Конституционного суда может назначить одного или нескольких судей-докладчиков по данному вопросу.

Дела могут быть объединены в единое производство, только если ни по одному из них не было начато рассмотрение по существу. Если по одному из дел, по тому же предмету, уже начато рассмотрение в судебном заседании, производство по другим делам, связанным с этим предметом, не должно осуществляться. Орган или лица, выступающие в качестве стороны в каждом объединенном деле, сохраняют в полном объеме свой правовой статус, даже после объединения дел в едином производстве.

Объединение дел в единое производство должно осуществляться определением Конституционного суда. Благодаря объеди- нению нескольких дел в едином производстве, обеспечивается полное и всестороннее расследование всех существенных обстоятельств, имеющих отношение к делу, экономится время и достигается значительное сокращение материальных и процедурных затрат.

Целью подготовительного этапа заседания Пленума Конституционного суда является сбор доказательств в еще большем объеме, по сравнению с гарантированием условий рассмотрения дела оперативным образом. Анализ практики, связанной с деятельностью Конституционного суда, а также нормативных правовых актов, регулирующих проводимые судьей-докладчиком подготовительные действия, дает основание для такого вывода. Судья-докладчик определяет предмет доказывания, встречается со сторонами и заявителями (привлекает их к сбору доказательств), запрашивает необходимые документы, организовывает проведение экспертиз, обращается к экспертам за экспертным заключением, проводит проверки, устанавливает круг лиц вызываемых на судебное заседание. Судья-докладчик является профессиональным судьей, поэтому у него формируется собственное мнение об исходе дела. Әто мнение находит свое отражение в проекте решения Конституционного суда.

Все документы, связанные с запросом, обращением или жалобой, хранятся у судьи-докладчика. После включения вопроса в повестку дня Конституционного суда, первичные экземпляры запроса, обращения или жалобы, все прилагаемые документы, заключения, полученные по запросу, обращению или жалобе, копии требований и запросов, отправленных судьей-докладчиком, ответы, полученные по запросам, экспертные заключения и мнения специалистов, а также документы, дополнительно полученные на подготовительном этапе заседания Пленума Конституционного суда, направляются в соответствующий отдел Аппарата Конституционного суда для составления конституционного дела и возврата всех документов судье-докладчику до начала заседания Пленума Конституционного Суда. Материалы дел, рассматриваемых Консти- 
туционным судом, не передаются в другие суды и организации.

Наряду с субъектами, указанными в статье 130-й Конституции Азербайджанской Республики, другие государственные органы и должностные лица также могут быть уведомлены о заседании Пленума Конституционного суда по делам о толковании Конституции Азербайджанской Республики. Представители этих государственных органов, должностные лица или их представители могут быть заслушаны на заседании Пленума Конституционного Суда.

\section{Аитература}

1. Конституция Азербайджанской Республики. Баку: Юридическая литература, 2012, 100 с. (на азербайджанском языке)

2. Абдуллаев Ф.С. Теоретические и практические проблемы конституционного производства в Азербайджанской Республике. Баку: Әлм, 2009, 396 с. (на азербайджанском языке)

3. Закон Азербайджанской Республики «О Конституционном Суде». Баку: Ганун, 2018, 60 с. (на азербайджанском языке)

4. Брежнев О.В. Защита основных прав и свобод граждан в Конституционном Суде: Дисс... канд. юрид. наук. М., 1997,$26 \mathrm{c.}$

5. Витрук Н.В. Конституционное правосудие. Учебное пособие. М.: Юристь, 1998, 381 c.

6. Комментарий к Федеральному конституционному закону «О Конституционном Суде РФ / Отв. ред. Н.В.Витрук, А.В.Аазарев, Б.С. Әбзеев. М.: Юридическая литература, 2006, 167 с.

7. Кряжков В.А., Аазарев А.В. Конституционная юстиция в Российской Феде- рации: Учебное пособие для вузов. М.: БЕК, 1998, 462 с.

8. Аучин В.О., Доронина О.Н. Жалобы граждан в Конституционный Суд Российской Федерации. М.: Норма, 2004, 268 с.

9. Хабриева Т.Я. Толкование Конституции. Теория и практика: Дисс...докт. юрид. наук. М., 1997, 224 с.

Nasib Shukurov - PhD in Law, Constitutional Law Department Baku State University

ACGEPTANCE BY THE CONSTITUTIONAL COURT OF THE REPUBLIC OF AZERBAIJAN OF REQUESTS AND APPEALS FOR CONSIDERATION AND PREPARATION FOR JUDICIAL CONSIDERATION

The article conducts a broad study of the important role of constitutional review during the improvement of the judicial legal system, examines the scope and sequence of cases in constitutional legal proceedings, as well as the substantive consideration of requests, appeals and complaints, and special constitutional proceedings.

In addition, the article discusses the importance of the report of the Judge-Rapporteur on the merits of the case in constitutional proceedings, the broad procedural rights of the chairman of the session of the Constitutional Court and the issues of attracting experts, witnesses, specialists and translators to participate in constitutional proceedings were also analyzed.

Key words: constitutional proceedings, requests, appeals and complaints filed with the constitutional court, special constitutional proceedings, Judge-Rapporteur, decision-making by the Constitutional Court. 